\title{
ロボットによる被覆操作のための教示方法
}

林直 宏* 冨 沢 哲 雄* 末 廣 尚 士* 工 藤 俊 亮*

\section{Teaching Method for Wrapping Operation by Robot}

Naohiro Hayashi*, Tetsuo Tomizawa*, Takashi Suehiro* and Shunsuke Kudoh*

\begin{abstract}
A purpose of this study is to achieve wrapping operation by robots. As a teaching method of wrapping operation, this study uses an intuitive instruction based on a movement of a hand, and generates robot commands from the instruction. This study represents wrapping operation based on a three-layered model as intermediate representation, which is originally proposed in our previous study. In this paper, as a key elements of this study, we describe the teaching method which is a part of inputting to the model. This method can understand an intention of the rough instruction and generate appropriate intermediate representation which represents the intention. In the intermediate representation, a part of hand path generation method is extended to loosen limitations about shapes of objects and fabric that can be handled. Finally, we integrate them into a total wrapping robot system, and confirm that the proposed method is effective to achieve wrapping operation by a robot.
\end{abstract}

Key Words: Manipulation, Deformable Object, Wrapping Operation, Robot Teaching

\section{1.はじめに}

近年，紐や布といった柔軟物の認識や，ロボットによる操作の 研究が活発化している. 布状柔軟物の認識の研究としては, 画 像情報や力覚情報から布の形状や把持点を探索する研究が挙げ られる $[1] \sim[6]$. 布状柔軟物操作の研究としては, 和田ら [7]の 平面上での布の同時位置合わせ作業, 柴田ら [8] の布展開動作, Abbeel ら [9] の衣服の折りたたみや, 寺田ら [10]の箱への風呂 敷包み, 稲葉ら [11], 柴田ら [12] の人間への着衣支援などが挙 げられる。これらの布状柔軟物に関する研究の中で, 本研究で は，ロボットによる物体への被覆操作を目指している. 例えば 風呂敷で物を包むといった物体への被覆操作は, 布状柔軟物の 重要な用途の一つであると言える。これまでの研究では, 布被 覆操作の記述に, ペアの点群 [7] [8], 折り紙に用いられるよう な折り線 [9] [10] や，布を持つ手先の経路[11] [12] が使用されて いる. しかし，様々な形状を持つ物体への被覆操作を考えた場 合，点や折り線による記述では曲面物体の表面への指示を行う ことが難しい. また, 手先経路による記述では, 逐一手作業に より経路の座標を指定しなければならず，経路を作成する人間 への負担が大きい.

人が人に包み方を指示するときは, Fig. 1 のように，大まか

原稿受付 2015 年 12 月 8 日

*電気通信大学

${ }^{*}$ The University of Electro-Communications

—本論文は新規性（要素分野）で評価されました，

口J-STAGE では本論文の電子付録として動画が閲覧できます.

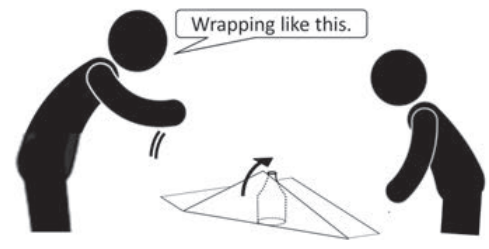

Fig. 1 Instruction of wrapping

な手の動きで示す，本論文では，この手の動きを「大まかな指 示」と呼ぶこととする。この大まかな指示は単に，布を包むとき の手の動きを直接表しているというよりも，布で物体のどこを 包むかという，布と物体の重なり合いを表しているものと考え られる. 本研究は, この大まかな指示で被覆操作を指示し, 口 ボットに被覆作業を行わせることを目標としている。このよう な，「動作の意図を表す大まかな指示」を理解し表現できれば， ユーザは指示内容を，細やかに考えて教えるのではなく，直感 的に伝えることができると期待できる，そのためには，被覆の 意図をどのような形で中間表現として記述するかが課題となる. しかし，初めに述べたように，既存の記述方法を用いて被覆操作 を表現することは難しく，代わりとなる記述方法が求められる.

そこで，大まかな動作指示と実際のロボット動作をつなぐ中 間表現として，本研究では「目標線」の概念を用いた手法を用 いる. 目標線という考え方自体はすでにCGの世界で用いられ てきており，五十嵐ら [13] や幸村 [14] の研究がその例である. この目標線は物体上と布上にそれぞれ対応するように引かれて いる，被覆時の布と物体の関係は，この目標線のペアが重なっ 


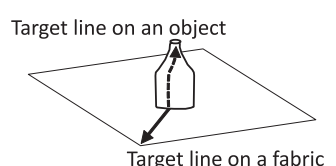

(a)

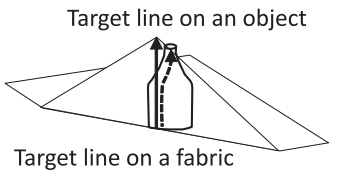

(b)
Fig. 2 (a) Target lines on a fabric section and an object (b) Wrapping an object with the target line of a fabric section placed onto the corresponding target line on the object

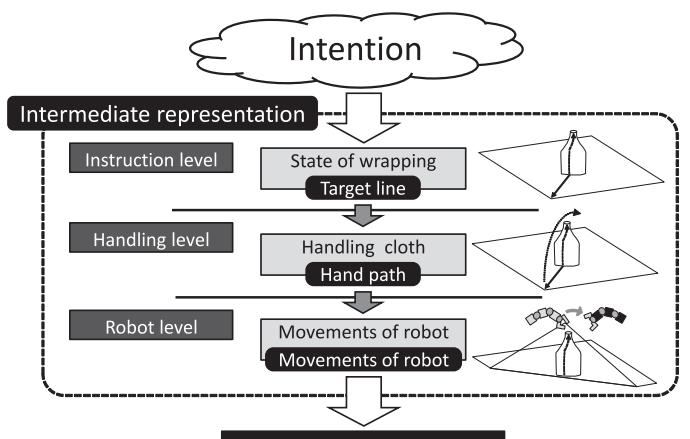

Robot command

Fig. 3 Intermediate representation of wrapping

た状態として表される（Fig. 2)。この目標線を用いた記述方法 は，様々な物体形状への被覆操作の記述に有用である。なぜな ら, 他の記述と比へ，平面だけでなく曲面形状への指示も行い やすく，また，どのような流れで，物体のどこを包むかという被 覆の本質的な目的を, 自然に表すことができるためである。こ れらの利点から, 本研究ではロボットのための被覆操作の中間 表現として，目標線を用いた方法を採用する.

しかし，実世界のロボットに被覆操作を行わせるためには， $\mathrm{CG}$ 分野で用いられるような目標線の記述だけでは十分とはい えない.なぜなら，記述どおりに包むためには，布を操作する手 先経路を目標線から計画しなければならないうえに，ロボット ごとの外形の違いや物体との干渉を考慮し, 適宜, 布の把持点 を変えたり, 左右の腕で布を持ち替えなければならないからで ある.すなわち, 目標線の記述からロボット自身の特性を考慮 して動作計画を行ったうえで, 操作を実行する必要がある。こ のように，目標線だけの記述だけではロボットを動作させるこ とはできず, 中間表現の中に, さらにロボットごとの動作に表 すステップも必要であると言える.

そこで筆者らは, まず文献[15] で中間表現として, 被覆操作 の目標線による記述方法, および三層構造を用いたモデル化を 提案した. そこではFig. 3 に示すように, 以下の三つの階層に 分けてロボットによる被覆操作のモデル化を提案した.

・インストラクションレベル：物体上と布上それぞれに対応 するよう引かれた目標線を用いて, 物体を包むための布の 重ね方を表す階層.

・ハンドリングレベル:把持点と, 把持点の経路（手先経路）を 用いて，布を物体に重ねるための布の動かし方を表す階層.

・ロボットレベル：個々のロボットに応じた記述（ロボット 動作）を用いて，ロボットの動作計画を表す階層.ロボッ

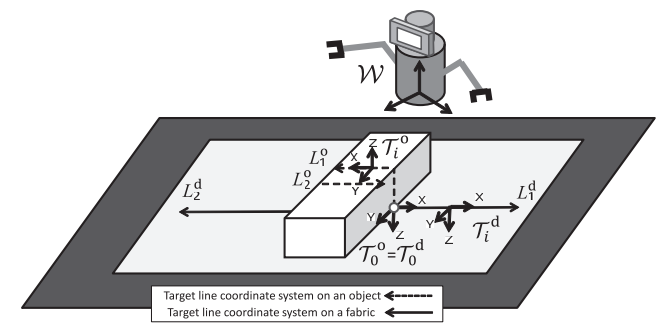

Fig. 4 Target lines on a fabric section and an object

トの外形などの特性を考慮し, 手先経路上での双腕ハンド での布の持ち替えや折䪶みの動作を計画する。

そして，目標線による被覆操作の記述から，ロボットのための 動作を生成する手法について述べた.

本論文では，これまで行ってこなかった部分として，人間の 大まかな指示に含まれている意図を理解し，適切な中間表現を 生成する手法について提案する。 また，中間表現からロボット 動作を生成する部分についても，扱える物体や布の範囲を広げ るための拡張を行う。大まかな指示を理解する上で問題となる のは，まず，物体の凹凸について，作業に用いる布のサイズに よって凹面を埋めるべきかの判断である。 そこで本論文では，凹 面を含むような複雑な形状の物体に対しても適切な被覆が実現 されるように，形状の局所的な凸性に着目して，布が覆いかぶ さる物体表面の領域（以降，被覆領域と呼ぶ）を適切に生成す る方法を提案する．次に問題となるのは，大まかな指示を行っ ているときに発生する手振れの影響である。そそこで，この手振 れの影響を補正し，適切に目標線を生成する方法を提案する。 また，中間表現からロボット動作を生成する部分について，文 献 [15] の中で報告した方法は, 長方形状の布であり, かつ, 布 の辺と平行な布上目標線にしか使用できない問題があった。そ こで本論文では，拡張した手先経路生成方法を提案する。そし て，これらを一連の被覆作業システムとして統合し，提案手法 がロボットへの被覆作業の教示に有効であることを示す.

本論文の構成としては 2 章では扮扮まかな指示を目標線に よって記述する方法, 3 章では目標線から手先経路を生成する 方法について述べる，4 章では実際のロボットによる, 本手法 を用いた被覆操作の実験について述べる．最後に 5 章で結論を 述べる.

\section{2. 目標線による大まかな指示の記述}

本章では, 目標線の定義と, 大まかな指示による教示を目標 線によって記述する方法について述べる.

\section{1 目標線の定義}

本論文では， $\mathcal{A}_{1}, \mathcal{A}_{2}$ の二つの座標系が与えられたとき, $\mathcal{A}_{1}$ から $\mathcal{A}_{2}$ への同時変換行列を式（1）の上うに表記する.

$$
{ }^{\mathcal{A}_{2}} T_{\mathcal{A}_{1}}=\left(\begin{array}{cc}
{ }^{\mathcal{A}_{2}} R_{\mathcal{A}_{1}} & { }^{\mathcal{A}_{2}} t_{\mathcal{A}_{1}} \\
\mathbf{0}_{3} & 1
\end{array}\right) \text {, where } \mathbf{0}_{3}=(0,0,0)
$$

ベクトル $v$ の座標系 $\mathcal{A}$ 上での表現を ${ }^{\mathcal{A}} v$ と表記する.

Fig. 4 に示すように, ワールド座標系を $\mathcal{W}$ とし，対応する 


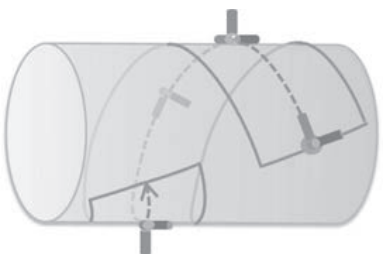

Fig. 5 Winding a fabric section diagonally

物体上・布上の目標線は $L_{j}^{\mathrm{o}}, L_{j}^{\mathrm{d}}$ と表す（ $j$ は目標線のインデッ クス). 各目標線には目標線座標系 $\mathcal{T}_{i}$ が張られており, 物体上 目標線座標系の位置成分を $t^{\circ}$ ，布上目標線座標系の位置成分を $t^{\mathrm{d}}$ とするとき，物体上目標線 ${ }^{\mathcal{W}} t_{\mathcal{T}}$ 。 間の間隔と布上の目標線 $\mathcal{W}_{t_{\mathcal{T}}}$ 間の間隔は対応するようになっている（式 $\left.(2)\right)$.

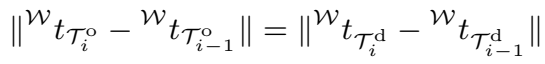

被覆操作を行うときには，この物体上の目標線座標系 $\mathcal{T}_{i}^{\circ}$ と布 上の目標線座標系 $\mathcal{T}_{i}^{\mathrm{d}}$ が重なるように操作する. 各目標線座標 系の $x$ 軸方向は目標線の進行方向を示す. 物体上の目標線座標 系の $z$ 軸方向は表面の法線を表し, 布上の目標線座標系の $z$ 軸 方向は物体と触れない側の面の法線を表す。この目標線座標系 $\mathcal{T}$ の張られた目標線 $L$ のペアを用いて，被覆する方向と，目 標の被覆状態を表す．目標線を用いれば，Fig. 5 に示すような， 円柱へ布を斜めに巻く操作も記述することができる.

\section{2 教示方法}

本節では, 被覆操作を教示する方法について述べる. 実際に ユーザが指示する環境としては，本手法では実空間で教示デバ イスを用いて教示を行う。この教示デバイスを用いることによ り, 大まかな指示による被覆操作の教示が可能となり, 教示内 容を目標線として記述することができる.

Fig. 6 に提案する教示方法を示す. ユーザは教示デバイスを 持ち，望みの被覆領域に向けて動かしていくことにより，シス テムが指示を理解し目標線を生成していく。この教示デバイス にはデプスセンサと磁気式のモーションセンサが取り付けられ ており，深度情報と教示デバイスの動きを取得することができ る.このデータから物体上の被覆領域を計測し, 目標線を生成 していく，モーションセンサより求まるデプスセンサの座標系 をKとし，デプスセンサは被覆に用いる布の幅 $d$ 分の線分を スキャンする（以降，得られた点群データをスキャンラインと 呼ぶ). 物体表面の向きを表すラインの始点 $t^{\mathrm{s}}$ ，終点 $t^{\mathrm{e}}$ として， 得られたスキャンラインを構成する点の集合 $S$ の端点を求め, この $t^{\mathrm{s}}, t^{\mathrm{e}}$ の中点を $t^{\mathrm{o}}$ とする. 本論文では, この $t^{\mathrm{s}}, t^{\mathrm{e}}$ で表 される線分をフイットラインと呼ぶこととする.

次に，このフィットラインとデプスセンサの座標系 $\mathcal{K}$ から物 体上目標線座標系 $\mathcal{T}^{\mathrm{O}}$ を求める方法について述べる. Fig. 7 中 央部に示す教示デバイスのデプスセンサ座標系 $\mathcal{K}_{i}$ から見た物

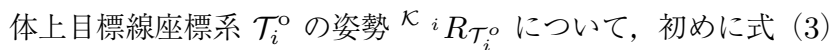
を用いて，フィットラインの単位ベクトル $f$ を Fig. 7 左上部に 示すように計算する.

$$
f=\frac{t_{i}^{\mathrm{e}}-t_{i}^{\mathrm{s}}}{\left\|t_{i}^{\mathrm{e}}-t_{i}^{\mathrm{s}}\right\|}
$$

次に，式（4）を用いて，Fig. 7 右上部に示すように $\mathcal{T}^{\circ}$ の $x$

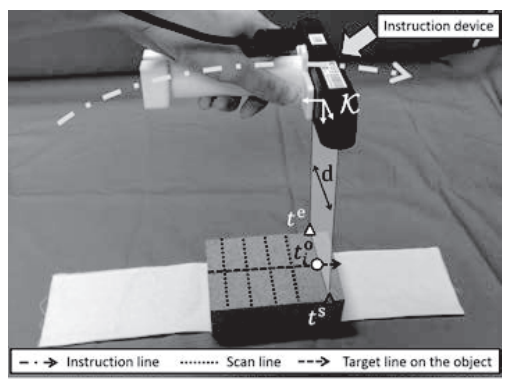

Fig. 6 Instruction of a target line on an object

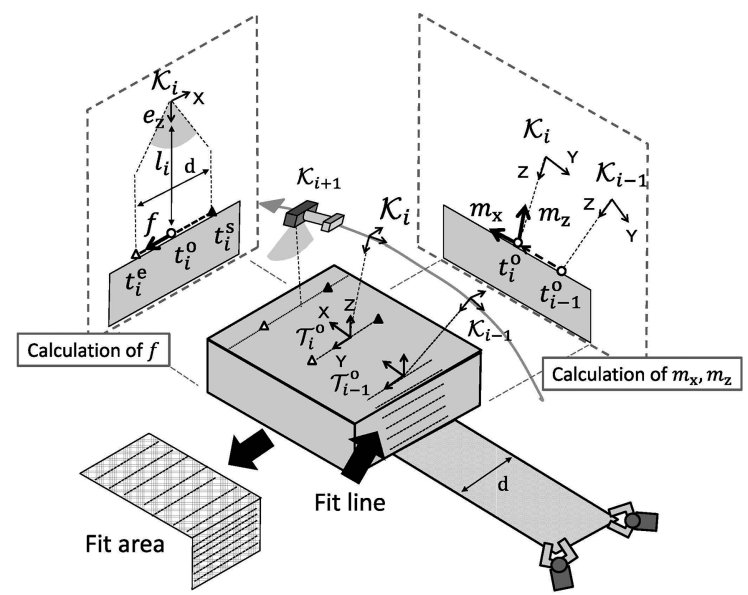

Fig. 7 Calculation of $\mathcal{T}^{\mathrm{o}}$

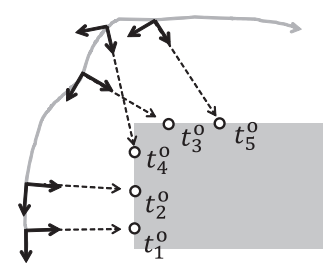

(a)

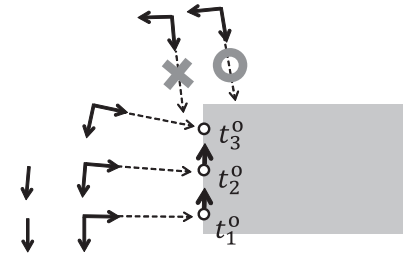

(b)
Fig. 8 Treated area (a) false instruction (b) true instruction

軸成分 $m_{x}$ を求める. この $m_{x}$ と $f$ から $m_{z}$ を求め, 最後に $m_{x}$ と $m_{z}$ から $m_{y}$ を求める. このようにして $\mathcal{T}^{\mathrm{o}}$ の軸成分か ら, $\mathcal{T}^{\mathrm{o}}$ の姿勢 ${ }^{\mathcal{K}_{i}} R_{\mathcal{T}_{i}^{\circ}}$ を求める.

$$
\begin{gathered}
\mathcal{K}_{i} R_{\mathcal{T}_{i}}=\left(m_{x} m_{y} m_{z}\right) \\
m_{x}=\frac{t_{i}^{\mathrm{o}}-t_{i-1}^{\mathrm{o}}}{\left\|t_{i}^{\mathrm{o}}-t_{i-1}^{\mathrm{o}}\right\|}, m_{z}=m_{x} \times f, m_{y}=m_{z} \times m_{x}
\end{gathered}
$$

また, Fig. 8 (a) に示すように, 教示デバイスを動かしている ときに，誤ってデバイスを傾けてしまい， $t_{3}^{\circ} \rightarrow t_{4}^{\mathrm{o}}$ のように目標 線が逆走してしまう場合がある. そこで，本手法では Fig. 8 (b) に示すように，記述済みの領域に再び目標線を引いてしまうの を防ぐ判定処理を用いる. 判定処理では Fig. 9 に示すように, 新たに入力された目標線 $t_{i}^{\mathrm{o}}$ が一つ前の $t_{i-1}^{\mathrm{o}}$ の表す領域と重複 していないか判定する，具体的には式（5）に示すように，記述 済みの領域に存在していないかを $v_{i}$ が閾值 $\alpha$ 以上の長さであ るかで判定し，かつ，急に目標線が曲がるような入力でないか 


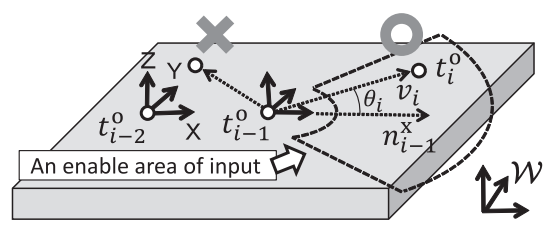

Fig. 9 Instruction of a target line on an object

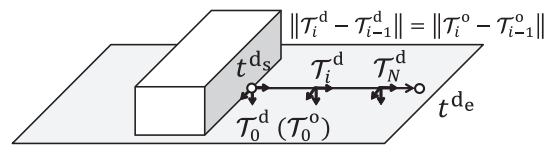

Fig. 10 Instruction of target line on fabric

を $\left|\theta_{i}\right|$ が $\beta$ 以内の角度にあるかで判定する. 例えば, 教示デバ イスで $t_{i-1}^{\mathrm{o}}$ まで入力されているとき, 逆走して式 (5) 判定外 のデータが入力されている間は目標線の更新が止まり, 再び判 定内のデータが入力されると $t_{i}^{\circ}$ から目標線が更新されていく.

$$
\left\|\mathbf{v}_{i}\right\|>\alpha \quad \text { かつ }\left|\theta_{i}\right|<\beta
$$

ただし，

$$
v_{i}=t_{i}^{o}-t_{i-1}^{o}, \quad \cos \theta_{i}=\frac{n_{i} \cdot v_{i}}{\left\|n_{i}\right\|\left\|v_{i}\right\|}, \quad n_{i}={ }^{\mathcal{W}_{\mathcal{T}_{i-1}}}\left(\begin{array}{l}
1 \\
0 \\
0
\end{array}\right)
$$

最後に布上目標線の入力方法について述べる. Fig. 10 に示 すように，1本の線分で表せる目標線を布上に入力する場合，初 期布上目標線として, 目標線の始点 $t^{\mathrm{d}_{\mathrm{s}}}$ と終点 $t^{\mathrm{d} \mathrm{e}}$ を教示デバ イスで決める。このとき, 布上目標線の始点は物体上目標線の 始点を用いるので, $t^{\mathrm{d}_{\mathrm{s}}}=t_{0}^{\mathrm{o}}$ となり, 終点 $t^{\mathrm{d}_{\mathrm{e}}}$ の方はデバイス でスキャンラインを1ラインだけ入力し, そこから求まるフィッ トライン中点の位置を終点とする. システムは布上目標線座標 系を，式（2）のように物体上の目標線座標系間の間隔に合わせ て, 始点 $t^{\mathrm{d}_{\mathrm{s}}}$ から, 始点と終点より表される線分方向に布上の 目標線座標系を配置する. 座標系の姿勢は式 (6) の上うに, 始 点終点入力時のフイットラインから計算する. これらのフイット ラインから求まる布の面（デバイスから反対側の方の面）の垂 線 $m_{z}$ と, 初期布上目標線の方向 $t^{\mathrm{d}_{\mathrm{e}}}-t^{\mathrm{d}_{\mathrm{s}}}$ を用いて座標系の 姿勢は定められる。このようにして布上目標線 $L_{j}^{\mathrm{d}}$ を生成する。

$$
\begin{gathered}
\mathcal{W}_{R_{\mathcal{T}^{d}}}=\left(m_{x} m_{y} m_{z}\right) \\
m_{x}=\frac{t^{\mathrm{d}_{\mathrm{e}}}-t^{\mathrm{d}_{\mathrm{s}}}}{\left\|t^{\mathrm{d}_{\mathrm{e}}}-t^{\mathrm{d}_{\mathrm{s}}}\right\|}, m_{z}=f \times m_{x}, m_{y}=m_{z} \times m_{x}
\end{gathered}
$$

このように，教示デバイスを用いた教示方法により，大まか な指示による被覆操作の教示が可能となり, その内容を目標線 として記述することができる.

\section{3 凹面への目標線指示}

\subsection{1 凹面への被覆指示}

前節では, 大まかな指示から目標線を生成する方法について 述べた。しかし，実際の物体形状には凹凸があり，被覆を行う ときは，その凹凸を考慮する必要がある．重力やハンドの引っ

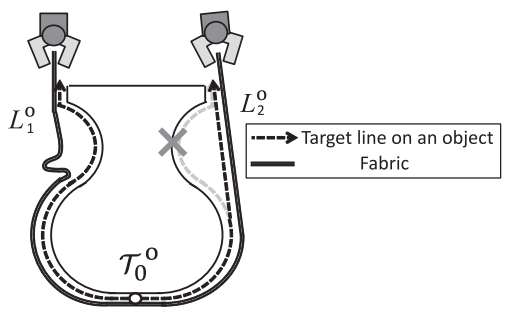

Fig. 11 Wrapping a concave surface

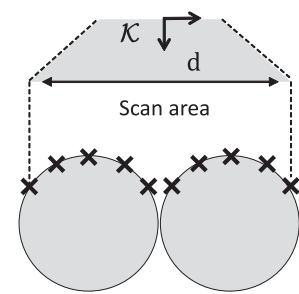

(a)

(c)

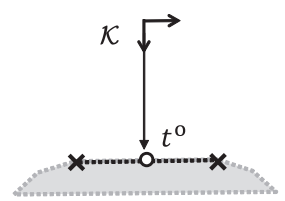

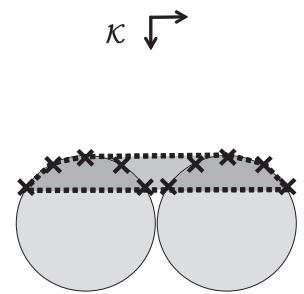

(b)

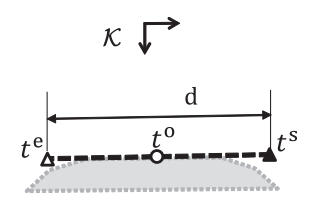

(d)

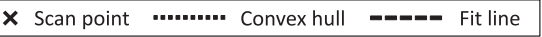

Fig. 12 Convex hull of a scan line

張る力を用いて凹面部分に布を入れ込むような被覆も挙げられ るが，本論文では布の幅より小さい凹面は避けて布で物体を覆 うという代表的な被覆を対象とする，また，本論文では，ユー ザからは重力方向を考慮した破綻のない指示が送られているこ とを前提とする，そのため，ハンドが操作を終了して布を放し た瞬間，布が剥がれ落ちるようなことはないものとする。これ らに基づき，本節ではその被覆に適切な凹凸の処理方法を提案 する．例えば，Fig. 11 に示すように，目標線を凹面に引いて も，実際は布の柔軟性のために，目標線 $L_{1}^{\circ}$ 側のように凹面に 布を被覆することはできない。そのため，物体上目標線 $L_{2}^{\circ}$ 側 のように，凹面上をショートカットするように目標線を引く必 要がある.ささらに, 実際の物体にはスキャンライン方向の物体 形状の凹凸と，目標線進行方向の凹凸を三次元的に考慮しなけ ればならない，それらを踏まえ，次項より凹面を考慮して目標 線を生成する方法について述べる。

\subsection{2 スキャンライン上での凸包処理}

本項ではスキャンライン上の凹凸の処理について述べる。初 めに， センサ座標系 $\mathcal{K}$ から得た布の幅 $d$ 分のスキャンライン を構成する点の集合 $S($ Fig. $12(\mathrm{a})$ ）の凸包多角形 $C H(S)$ を 求める (Fig. $12(\mathrm{~b}))$. この $C H(S)$ について，センサ座標系 $\mathcal{K}$ から見て $C H(S)$ の上包と, センサ座標系の $\mathrm{z}$ 軸の延長線の交 点を $t^{\circ}$ とする (Fig. 12 (c)). そして， $t^{\mathrm{O}}$ を含む上包の線分を $t^{\circ}$ を中心に布の幅 $d$ の長さまで延長し，フイットラインとする (Fig.12(d))。これにより，スキャンライン上での凹部分の凸 化ができる. 


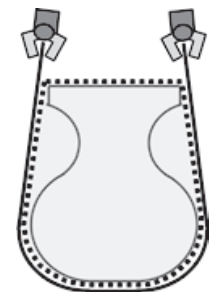

(a)

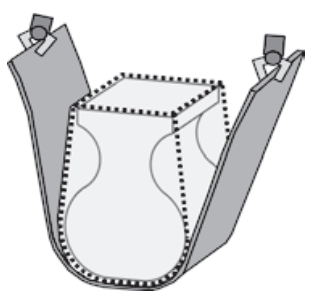

(b)
Fig. 13 Global Convex hull (a) on 2D (b) on 3D

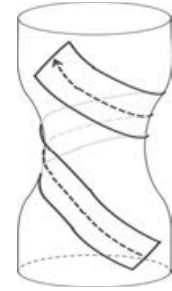

(a)

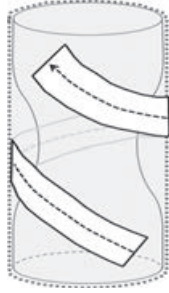

(b)
Fig. 14 Global convex hull (a) desired wrapping area (b) convex hull of the object

\subsection{3 スキャンライン間での凸包処理}

本項ではスキャンライン間での凸包化処理を行い被覆領域を 凸化する処理について説明する. 前項より, 入力された各スキャ ンラインは凸化され，被覆領域はフィットライン群（フィットラ インの始点, 終点の点群 $\left.F=t_{i}^{\mathrm{s}}, t_{i}^{\mathrm{e}}\right)$ として表される, 本手法 は，このフイットライン群に対し凸化処理を行う.

その前にここで, 三次元物体上の被覆領域への凸包化の問題に ついて述べる. 一般的な凸包化処理とは, ある形状の物体や物体 群について形状の凹部を埋め凸包を生成するものであり [16] [17], 通常行われる物体形状全体の凸包化は global convex hull と呼ば れる．また，関連して，物体形状の凹凸を数值化する convexity measurement，凹凸から物体を大まかなセグメントに分割する Convex decomposition [18]〜 [20] の研究も挙げられる.

次に，被覆領域生成に global convex hull を用いた場合の例 をFig. 13 に示す. Fig. 13 (a) に示すように，凹面を持つ形状 に布を被覆する場合は，物体に凸包化処理を行い，凹部分を避 けた面に被覆領域を生成する必要がある。 また, Fig. 13 (b) に 示すような，凹面を持つ三次元物体に布を被覆する場合でも，物 体に凸包化処理を行えば凹部分を避けた被覆領域を生成するこ とができると思える. しかし，Fig. 14 (a) に示すような巻き付 けを含む被覆を望む場合に，Fig. 13 (b) に行った global convex hull 処理を用い凹領域を埋めた場合, Fig. 14 (b) に示すような 被覆領域を生成してしまう。この被覆領域を用いた場合，ロボッ 卜は布を何もない領域に巻き付けようとするため布が弛んでし まい，目標どおりの巻き付けを行うことができない。このよう に，一般的な global convex hull 処理では，布の幅を考慮した 被覆に最適な凸面領域を適切に生成することはできない。また， 関連する物体形状全体の凹凸の数值化や，大まかな形状分割手 法に関しても, global convex hullのように物体全体を基に凹 凸を扱っていくので, 被覆に適した凸化処理を行うことはでき

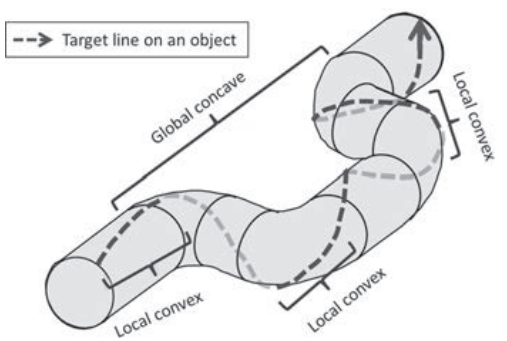

Fig. 15 Global concave and local convex

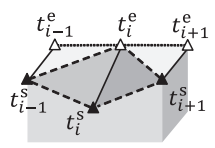

(a)

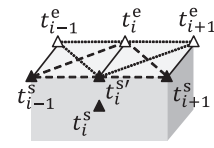

(b)

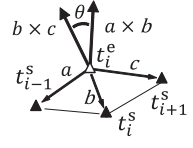

(c)
Fig. 16 Local convex hull (a) initial wrapping area (b) optmized wrapping area (c) calculation of an angle

ない.

そこで，まず，三次元物体上の被覆領域に求められる凹凸形 状の条件について論じる. 被覆に理想的な領域は, Fig. 14 のよ うに入力された領域全体で凸包の性質を持つということではな く，Fig. 15 に示すように，領域中の至る所で局所的な凸包の 性質を持てばいいと言える，本研究における局所的な凸包とは， あるフィットラインとその前後のフィットラインから構成される 局所領域が凸面であるということを意味し，領域中の至る所で 局所的な凸包の性質を持つ場合，被覆領域が凸であると呼ぶこ ととし，凸な領域に目標線が引かれているとき，目標線は凸で あると呼ぶこととする。

次に，この条件を満たす被覆領域を生成する提案方法につい て述べる．初めに，ある局所領域の凹凸判定する方法について 述べる. Fig. 16 (a) に示すように，あるフィットラインと，そ の前後のフィットラインからなる領域について, $\triangle\left(t_{i}^{\mathrm{s}}, t_{i}^{\mathrm{e}}, t_{i-1}^{\mathrm{s}}\right)$ と $\triangle\left(t_{i}^{\mathrm{s}}, t_{i}^{\mathrm{e}}, t_{i+1}^{\mathrm{s}}\right)$ の二つの三角形の垂線どうしが成す角度 $\theta_{i}^{s}$ を 式（7）加求める（Fig. $16(\mathrm{c})$ ).

$$
\sin \theta^{\mathrm{s}}=\frac{\|(a \times b) \times(b \times c)\|}{\|a \times b\|\|b \times c\|}
$$

ただし，

$$
a=t_{i-1}^{\mathrm{s}}-t_{i}^{\mathrm{e}}, \quad b=t_{i}^{\mathrm{s}}-t_{i}^{\mathrm{e}}, \quad c=t_{i+1}^{\mathrm{s}}-t_{i}^{\mathrm{e}}
$$

このように $\theta_{j}^{\mathrm{s}}$ を求める処理を, これ以降 $\theta_{i}^{\mathrm{s}}=\operatorname{CalAngle}(\triangle$ $\left.\left(t_{i}^{\mathrm{s}}, t_{i}^{\mathrm{e}}, t_{i-1}^{\mathrm{s}}\right), \triangle\left(t_{i}^{\mathrm{s}}, t_{i}^{\mathrm{e}}, t_{i+1}^{\mathrm{s}}\right)\right)$ と書くことにする。この角度が負 の場合，二つの三角形で表されている面は凹面であるので，凸 包化処理を行う。このとき，一般的な凸包化方法では凹面を塞 ぐため, $t_{i-1}^{\mathrm{s}} \sim t_{i+1}^{\mathrm{s}}$ 間を繋ぎ， $t_{i}^{\mathrm{s}}$ を消去してしまうが，提案 方法では Fig. 16 (b) に示すようにフイットラインの端点として 残すために， $t_{i-1}^{\mathrm{s}}$ と $t_{i+1}^{\mathrm{s}}$ の中点を補完点 $t_{i}^{\mathrm{s}^{\prime}}$ として作成する. このようにして被覆領域を表す点群を更新する。この処理内容 を $\triangle\left(t_{i}^{\mathrm{e}}, t_{i}^{\mathrm{s}}, t_{i-1}^{\mathrm{e}}\right)$ と $\triangle\left(t_{i}^{\mathrm{e}}, t_{i}^{\mathrm{s}}, t_{i+1}^{\mathrm{e}}\right)$ の側についても, 同様に行 う.そして，すべての $\theta_{j}^{\mathrm{s}}, \theta_{j}^{\mathrm{e}}(j=2, \cdots N-1)$ が非負となる ように，これらの Convex hull 処理を含む Algorithm に示す 


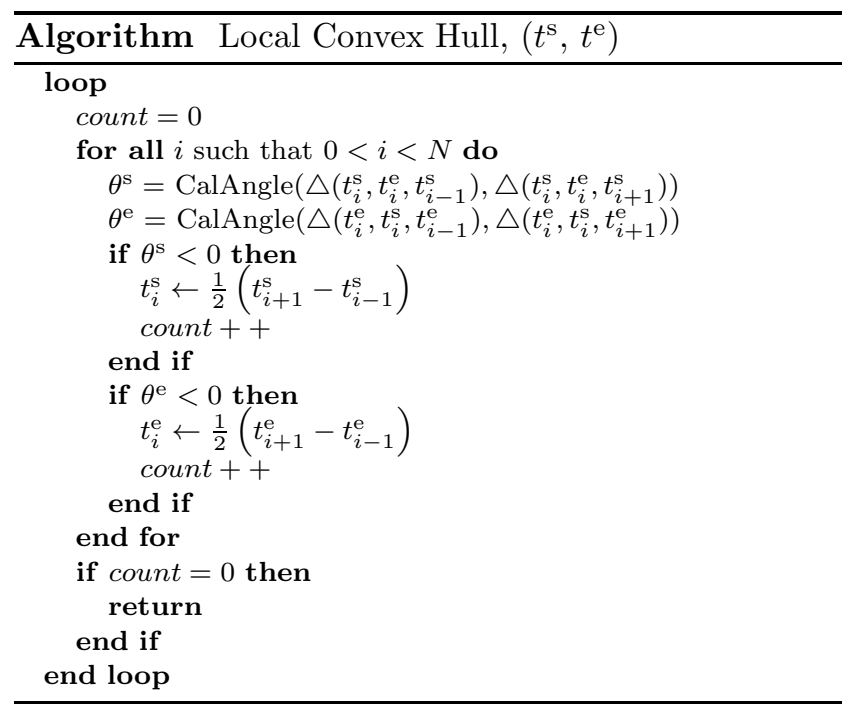

処理を行う.

この Algorithm は局所的な凸包化処理をフイットラインの シーケンス内で繰り返し行うことにより凹部分を埋めていくこ とができる。これにより局所凸包の性質を持つ被覆に適した領 域を生成することができる，以上のようにして，フィットライ ンシーケンス上で提案方法の局所凸包化処理を行うことにより, 既存の凸包処理では生成できなかった，被覆に適した到る所凸 の領域生成，および目標線の指示が可能となる.

\section{4 目標線の補正処理}

ここでは，目標線への手振れの影響を補正する方法について 述べる. 教示デバイスによる目標線入力時, 直線を入力したつ もりでも手の振れによって，目標線も振れてしまう場合がある. 目標線の入力については 2.2 節の式 (5) で定義したように, 線 が急に逆走したり，大きく離れた所に入力されないものとして いる. よって, この教示デバイスに伴う手の振れとは, 入力し たい目標線の進行方向に対する垂線方向でのずれである. 物体 へは直線や緩やかな曲線形状の目標線を入力することが多いた め, 提案方法は, この直線や緩やかな曲線の目標線の入力を可 能にするための補正を行う。そこで, 必要となる線を滑らかに する方法としては, 線を構成する点の位置を補正するスプライ ン補間等が一般的に挙げられるが，これらの補正をそのまま物 体上目標線に行った場合，Fig. 17のように角上では物体内に めり込むような形で補正してしまう場合がある。 そのため，提 案方法では式（8）のように目標線が物体表面上にあるのを保 つような補正を行う。具体的には，スプライン補間で滑らかに した目標線（Fig. 18(a)）を物体表面上へ補正目標線として射 影する.このとき，まず，滑らかにした目標線を元のフィット ライン上あるいはその延長線上に射影する方法が考えられるが， Fig. 18 (b) のように, 手振れにより物体の角付近のフィットラ インが傾いている時は, 射影した目標線が物体表面より離れて しまう場合がある．そこで，提案方法では Fig. 18 (c) のように， 元の物体上目標線座標系で表される物体表面に射影する。これ により, 目標線補正時の物体へのめり込みを防ぎつつ, 線を滑 らかにすることができる.

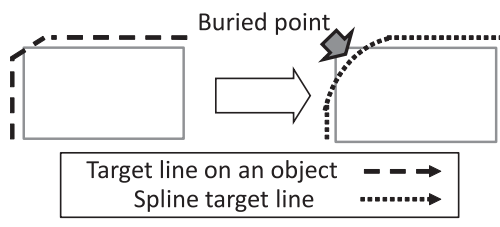

Fig. 17 Buried point in an object

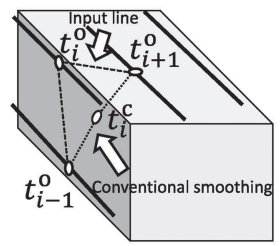

(a)

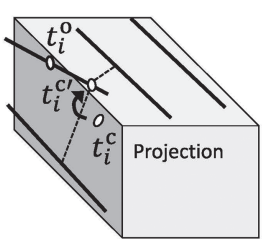

(b)

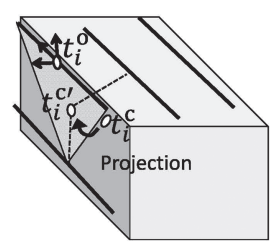

(c)
Fig. 18 Projection of spline points (a) spline interporation (b) projection on the plane

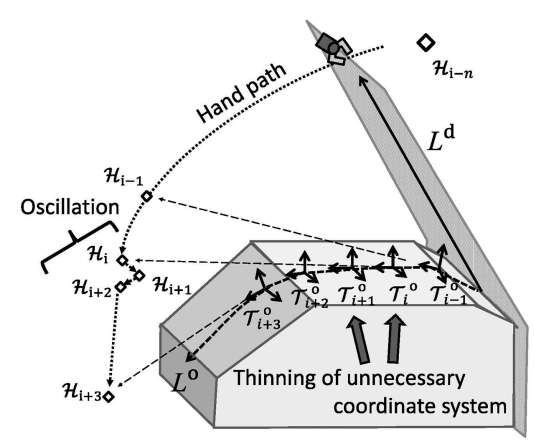

Fig. 19 Swinging hand path in a straight line part of the target line

$$
t_{i}^{\mathrm{c}^{\prime}}=t_{i}^{\mathrm{c}}-m_{i} n_{i}^{z}
$$

ただし，

$$
\begin{gathered}
n_{i}^{z}={ }^{\mathcal{W}} R_{\mathcal{T}_{i}^{\mathrm{o}}}(0,0,1)^{\mathrm{T}}, m_{i}=n_{i}^{z} \cdot\left(t_{i}^{\mathrm{c}}-t_{i}^{\mathrm{o}}\right), \\
t_{i}^{\mathrm{c}}=(1-s)^{2} t_{i+1}^{\mathrm{o}}+2 s(1-s) t_{i}^{\mathrm{o}}+s^{2} t_{i-1}^{\mathrm{o}} \quad, \quad(s=0.5)
\end{gathered}
$$

次に, 目標線座標系列の姿勢成分を考慮して, 補正目標線の 直線部分の間引き処理を行う。これを行う理由としては，3 章で 述べる手先経路（目標線より生成される布を動かすための手先 経路）に影響があるためである. Fig. 19 に示すように，本来， 直線状に並ぶ物体上目標線座標系 $\mathcal{T}_{i}^{\mathrm{O}} \sim \mathcal{T}_{i+2}^{\mathrm{O}}$ から生成される手 先位置 $\mathcal{H}_{i} \sim \mathcal{H}_{i+2}$ は同じ位置を指すべきである. しかし，実 際は入力の手振れの影響により $\mathcal{T}_{i}^{\mathrm{o}} \sim \mathcal{T}_{i+2}^{\mathrm{o}}$ 間も振れ, $\mathcal{H}_{i}$ 付近 で余分に振れる手先経路となってしまう。そこで，式（9）に示 すように，二つの目標線座標系 $\mathcal{T}_{i}^{\mathrm{o}}, \mathcal{T}_{j}^{\mathrm{o}}(j=i+1, i+2, \cdots N)$ 


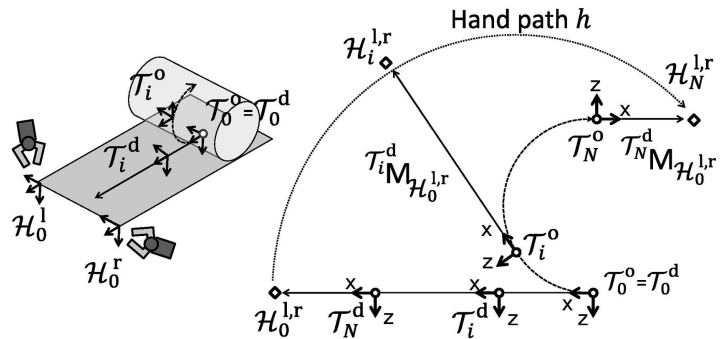

Fig. 20 Generation of hand pathes

の目標線の方向を表す $\mathrm{x}$ 軸どうし, 布が重なる方向を表す $\mathrm{z}$ 軸 どうしがなす角度 $\theta_{i, j}^{x}, \theta_{i, j}^{z}$ を求める.

$$
\theta_{i, j}^{x}<\beta_{x} \text { かつ } \theta_{i, j}^{z}<\beta_{z}
$$

ただし，

$$
\begin{gathered}
\cos \theta_{i, j}^{x}=\frac{n_{i}^{x} \cdot n_{j}^{x}}{\left\|n_{i}^{x}\right\|\left\|n_{j}^{x}\right\|}, \quad \cos \theta_{i, j}^{z}=\frac{n_{i}^{z} \cdot n_{j}^{z}}{\left\|n_{i}^{z}\right\|\left\|n_{j}^{z}\right\|} \\
\left(n_{k}^{x}={ }^{\mathcal{W}} R_{\mathcal{T}_{k}^{\circ}}(1,0,0)^{\mathrm{T}}, n_{k}^{z}={ }^{\mathcal{W}} R_{\mathcal{T}_{k}^{\circ}}(0,0,1)^{\mathrm{T}}, k=i, j\right)
\end{gathered}
$$

そして, $\mathcal{T}_{i}^{\mathrm{o}}$ から $\mathcal{T}_{i+2}^{\mathrm{o}}$ までのそれぞれの角度が闇值 $\beta_{x}, \beta_{z}$ 以下だった場合，同じ平面上にある目標線の直線部分であると みなし, 直線上の近しい姿勢の目標線座標系 $\mathcal{T}_{i}^{\mathrm{o}} \sim \mathcal{T}_{i+1}^{\mathrm{o}}$ を間 引く. そして, 間引いた分 $\mathcal{T}_{i+2}^{\circ}$ 以降の座標系のインデックス を $i$ 番めから振りなおす.このようにして, 細かな振れを減ら す処理を施す. 本システムは, これらの物体上目標線の補正処 理によって，手振れの影響を軽減することができる.

\section{3. 目標線からの手先経路生成}

本章では, 目標線から布を動かすための手先経路を生成する 方法について述べる. 手先経路生成方法については文献[15] で 報告を行っているが, 以前の提案方法は長方形の布で, 辺に平行 な布上目標線にしか対応していなかったため, 本論文では, そ れ以外にも対応するように改良した手先経路生成方法を述べる.

\section{1 手先経路生成}

手先経路生成方法は目標線と布の把持点の関係から, 実際に布 を動かすための右手と左手の手先経路 $h^{\mathrm{r}}, h^{1}$ を生成する. 実際 には，手先経路上に座標系 $\mathcal{H}_{i}^{\mathrm{r}}, \mathcal{H}_{i}^{1}(i=0,1, \cdots)$ を考え，ワー ルド座標系 $\mathcal{W}$ からの同次座標変換行列を求める (式 $(10))$.

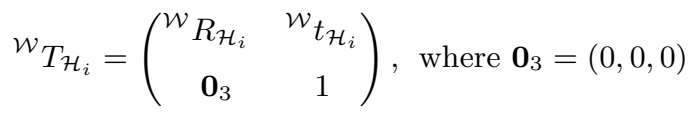

ロボットが布を把持する位置として，両手で把持する場合は， 被覆開始時点の右手と左手の手先経路座標系 $\mathcal{H}_{0}^{\mathrm{r}}, \mathcal{H}_{0}^{1}$ を設定す る. Fig. 20 左部に示すように，この被覆開始時点の手先経路 座標系を手先経路の始点とし, 手先経路を生成していく. $i$ 番 めの物体上と布上目標線座標系どうしを重ねるための右手と左 手の手先経路座標系 $\mathcal{H}_{i}^{\mathrm{r}}, \mathcal{H}_{i}^{1}$ は, 布上目標線座標系 $\mathcal{T}_{i}^{\mathrm{d}}$ と手先 経路座標系 $\mathcal{H}_{0}$ との初期位置関係, 物体上目標線座標系 $\mathcal{T}_{i}^{\circ}$ よ り求める (Fig. 20 右部). 手先経路座標系 $\mathcal{H}_{0}$ から布上目標線 座標系 $\mathcal{T}_{i}^{\mathrm{d}}$ への同時変換行列を $\mathcal{T}_{i}^{\mathrm{d}} T_{\mathcal{H}_{0}}$ とするとき, 手先経路

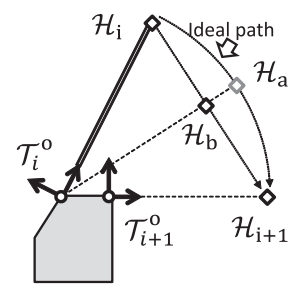

(a)

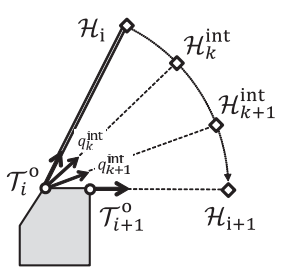

(b)
Fig. 21 Interpolation of a hand path section

座標系からワールド座標系への同時変換行列は, 式 (11) に示 すように計算する.

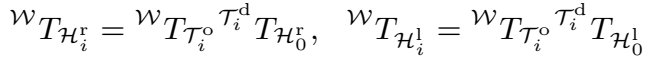

本論文では今回, 布の力学モデルや状態フィードバックを用 いた, 高精度の位置合わせ作業は対象としていない. 本研究は 初期目標として，人間の日常的な包む動作のような，大まかに 布を合わせる操作の実現を目指しているためである. そのため, 今回の操作では布の弛みの考慮は行わないものとする. それに より, 手先位置が $\mathcal{H}_{i}$ で $i$ 番めの目標線座標系どうしまでが重 なっているとき, 布上目標線座標系 $\mathcal{T}_{i}^{\mathrm{d}}$ から手先位置 $\mathcal{H}_{i}$ まで の布は, 弛まずに平面形状を保っていると見なす.この手先経路 生成方法により，目標線から手先経路を生成することができる.

\section{2 手先経路の補正処理}

物体の角上での目標線から生成される手先経路はFig. 21 (a) のような $\mathcal{H}_{i}, \mathcal{H}_{i+1}$ を結ぶ直線経路となる. 布の把持点 $\mathcal{H}_{i}$ と $\mathcal{T}_{i}^{\mathrm{o}}$ の位置関係を布に維持したまま, $\mathcal{H}_{i+1}$ まで手先を移動させ ることを考慮すると， $\mathcal{H}_{a}$ を経由するような円弧上の経路で布 を移動させるのが理想的である。このように， $\mathcal{H}_{i}, \mathcal{H}_{i+1}$ 間の 中点を $\mathcal{H}_{b}$ とすると, 物体上目標線座標 $\mathcal{T}_{i}^{\mathrm{o}}, \mathcal{T}_{i+1}^{\mathrm{o}}$ 間の姿勢が 大きく変わるほど, $\mathcal{H}_{a}$ と $\mathcal{H}_{b}$ の差が大きくなってしまう.この 問題を避けるために，本手法では二つの目標線座標系 $\mathcal{T}_{i}, \mathcal{T}_{i+1}$ の姿勢変化 $\theta_{i, i+1}^{x}$ が閾值 $\beta_{h}$ 以上の場合, 経路間を円弧状に補 間する (Fig. $21(\mathrm{~b})$ ). ワールド座標系から見た目標線座標系 $\mathcal{T}_{i}$ の姿勢のクォータニオンを $q^{\mathcal{T}_{i}}$ とし，二つの目標線座標系間を $n$ 分割して円弧補間する. そのために式（12）に示すように, クォータニオンの球面線形補間を用いて二つの目標線座標系姿 勢間の補間姿勢 $q_{k}^{\text {int }}$ を生成し，これを元に，円弧状に補間する 手先姿勢 $\mathcal{H}_{k}^{\text {int }}$ を配置する。 この補間手先姿勢 $\mathcal{H}_{k}^{\text {int }}$ を経由して 手先を移動させる. この補正処理によって, 移動中の布と把持 点の位置関係を変えずに，布を動かすことができる.

$$
q_{k}^{\text {int }}=\frac{\sin \left(\left(1-\frac{k}{n}\right) \omega\right)}{\sin \omega} q^{\mathcal{T}_{i}}+\frac{\sin \left(\frac{k}{n} \omega\right)}{\sin \omega} q^{\mathcal{T}_{i+1}}
$$

ただし，

$$
\omega=\cos ^{-1}\left(q^{\mathcal{T}_{i}} \cdot q^{\mathcal{T}_{i+1}}\right), \quad(k=0,1, \cdots, n)
$$




\section{4. 実}

験

\section{1 実験環境}

まず，本システムは 1 章で述べた被覆操作の 3 階層モデル化 に基づき, 各機能がROS [21] のモジュール群として実装され ている（Fig. 22）。インストラクションレベルでは, 教示デバ イスによるオペレータの教示データから，2 章で述べた目標線 生成方法を用いて，目標線を生成している，ハンドリングレベ ルでは，この目標線から，3章で述べた手先経路生成方法を用 いて，手先経路を生成している，ロボットレベルでは，この手 先経路から, 逆運動学計算モジュール等を用いて, 最終的なロ ボットの関節動作計画を生成している。このように，教示デバ イスによるオペレータの教示データが階層モデルを経て, 最終 的なロボットの関節動作計画に変換され，これをロボットに送 ることにより，ロボットが被覆操作を行うことができる.

次に, 教示に用いたデバイス（Fig. 23 (a)）は, デプスセンサ (asus 製 xtion), 磁気式モーションキャプチャ装置（polhemus 製 fastrak）を作成したグリッパに取り付けたものであり，デプ

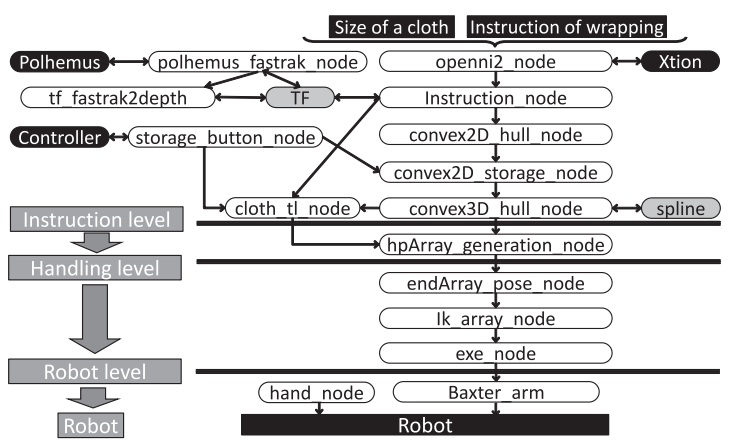

Fig. 22 System overview

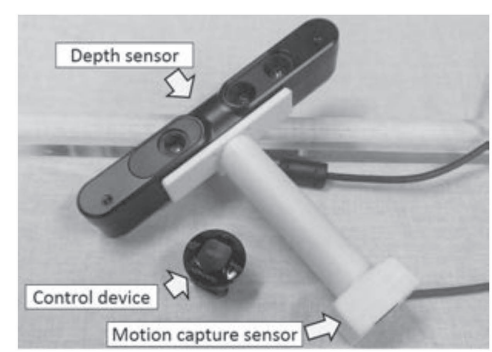

(a)

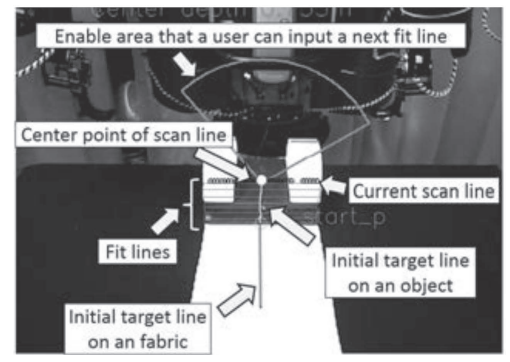

(b)

Fig. 23 An instruction device (a) the appearance (b) the graphical feedback display
スセンサ座標系とモーションキャプチャ装置の座標系は事前に キャリブレーション済みである，また，デバイスをコントロール するために，指輪型プレゼンツール（コクヨ製 ELA-FP1）を 用いた，各ボタンには入力機能として，ボタンを押している間， フィットラインの入力が行われる，強制的に現在のフィットライ ンを入力する，現在のフィットラインを消すなどを割り当てた. Fig. 23 (b) は，教示中に入力を確認するためのフィードバック ディスプレイであり，デバイスの RGB カメラ画像が映る画面 中には，現在のスキャンラインや入力された目標線，フイット ライン群などの情報が表示される.

以降の実験について，2.2 節の式（5）で述べた目標線入力判 定の閯值は， $\alpha$ は $1[\mathrm{~cm}], \beta$ は $45^{\circ}$ とした. なお，これらのパ ラメータは物体の形状や, スキャンラインで表される被覆領域 が要求する再現精度を考慮して設定する.

\section{2 目標線入力の手振れ補正}

本節の実験では，2 章で提案した教示デバイスを用いた目標線 の入力, 目標線および手先経路の手振れ補正方法について評価 を行う. 4.2.1 項では, 教示デバイスで目標線を入力したときの 目標線自体の誤差抢よび，提案補正方法の効果について述べる. 4.2.2 項では，スムージング処理による物体への目標線めり込 み問題（Fig. 17）に対して, 提案補正方法の効果について述べ る. 4.2 .3 項では, 目標線補正処理の最終的な手先経路への効 果について述べる。これらより，手振れの影響を減少し，入力 したい目標線が作成され，手先経路が生成できることを示す.

\subsection{1 目標線入力および補正実験}

この実験では，教示デバイスを用いた教示から目標線の入力 を行う．教示デバイスを用いて入力したい主な目標線は，直線 と，緩やかな曲線である，そこで，本実験では直線と緩やかな 曲線を入力目標線とする.この入力目標線と実際に入力された 目標線との誤差を求める。 また，線に乗る手振れのノイズを 2.4 節で述べた補正処理で軽減した場合の，入力目標と補正後の目 標線との誤差についても評価を行う。入力する直線，曲線は以 下のガイドラインの線とする.

Case1: Fig. $24(\mathrm{a})$ のように, $36[\mathrm{~cm}]$ の高さの机の上に $50[\mathrm{~cm}]$ の直線ガイドラインを配置.

Case2: Fig. 24 (b) のように, $36[\mathrm{~cm}]$ の高さの机の上に半径 $10[\mathrm{~cm}]$ の円柱上に円周 $90^{\circ}$ 分の曲線ガイドラインを配置.

実際の入力時には，ガイドラインを紙で隠した状態で，元の ガイドラインと同じようになるように目標線の入力を行う。今 回の教示デバイスの最短センシング距離は $80[\mathrm{~cm}]$ であり，実 験中はそれ以上離れた高さで入力作業を行っている．入力は以

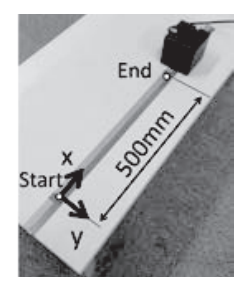

(a)

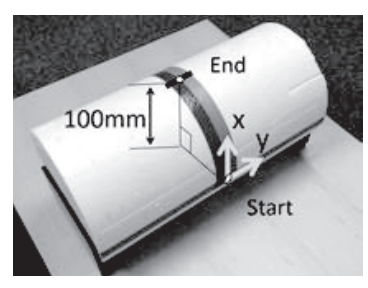

(b)
Fig. 24 Condition of the instruction (a) a line (b) a curve line 
Table 1 Result of the instruction (Standard deviation)

\begin{tabular}{|c||c|c||c|c|}
\hline \multicolumn{1}{|c||}{} & \multicolumn{2}{c||}{ Case1(line) } & \multicolumn{2}{c|}{ Case2(curve line) } \\
\hline & $\mu_{x}[\mathrm{~mm}]$ & $\mu_{\theta}\left[^{\circ}\right]$ & $\mu_{x}[\mathrm{~mm}]$ & $\mu_{\theta}\left[^{\circ}\right]$ \\
\hline \hline Input & $4.8(2.2)$ & $3.85(0.84)$ & $5.1(2.5)$ & $1.5(0.6)$ \\
\hline Smoothing & $4.1(1.9)$ & $0.63(0.42)$ & $5.0(2.5)$ & $0.6(0.2)$ \\
\hline
\end{tabular}

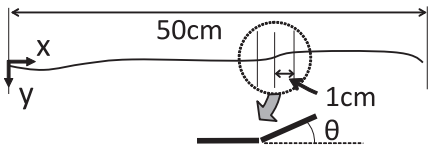

(a) segment of the line

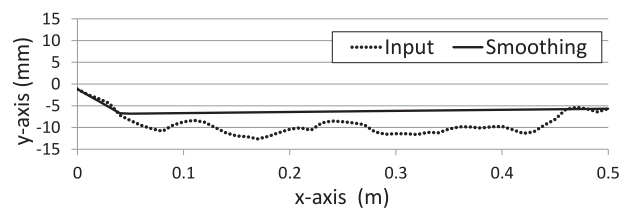

(b) result1

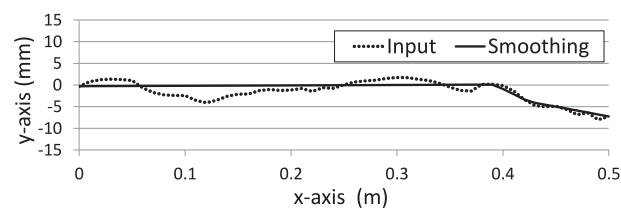

(c) result2

Fig. 25 Result of smoothing

下の条件で, 10 回ずつ入力を行う.

・線の始点としてスタートポイントはあらかじめ入力してある。

・フィードバックディスプレイを見ながらデバイスで入力する.

・スタートからゴールまで手を止めず，動かし続けて入力する。 実際に入力した目標線 (Input) に提案補正処理を行い, 補正目 標線（Smoothing）を生成する。これらの線（Input, Smoothing）の滑らかさを測る. 本実験では，Fig. 25 (a) に示すよう に, 直線は $\mathrm{y}$ 軸方向 $1[\mathrm{~cm}]$ ごと, 緩やかな曲線は円周方向 $1^{\circ}$ ごとに線分として分割し，手振れによる線の振れとして，隣り 合う線分どうしの $\mathrm{x}$ 軸成分の角度を計算する。この線分どうし の成す角度の線全体での絶対值平均角度を滑らかさの指標とし て，入力した線ごとに求める.

Table 1 に結果として, 入力 10 回分のガイドラインと目標 線の $\mathrm{x}$ 軸方向の誤差の絶対值平均 $\mu_{x}$ と絶対值平均角度の 10 回 分の平均角 $\mu_{\theta}$ を示す (カッコ内は標準偏差). まず，平均誤差 は $5[\mathrm{~mm}]$ 前後に収まり，そして，Case1，2 とも，補正処理に より，平均角度が角度が小さくなり，入力された目標線の手振 れの影響を減少させていることが分かる．特に，平面上に入力 したCase1（直線状の目標線）は間引き処理の効果で，入力し た目標線と比較して, 補正後の目標線は角度の絶対值平均角度 が大幅に小さくなっている。この間引き処理の効果の典型例と して, Fig. 25 (b), (c) に Case1 の入力した目標線と補正目標線 を示す。このように，手振れの影響により振れている目標線が 補正処理により滑らかにされ, 直線に近づけられているのが分 かる．また，さらに実験 4.2.3 項では，本実験の目標線を滑ら かにした結果が，具体的に実際の被覆操作に必要な手先経路に どのような効果をもたらすかを示す。
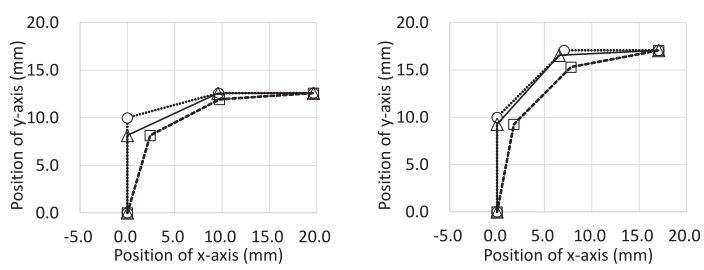

(a) an edge form of a target line $\left(15^{\circ}\right)$

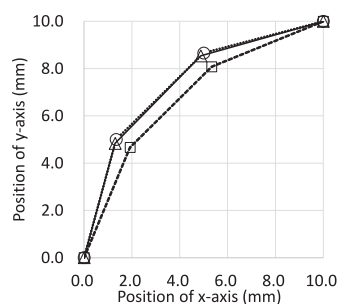

(b) an edge form of a target line $\left(45^{\circ}\right)$

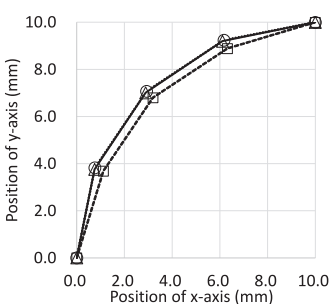

(c) a curve form of a target line (3segments)

(d) a curve form of a target line (4segments)

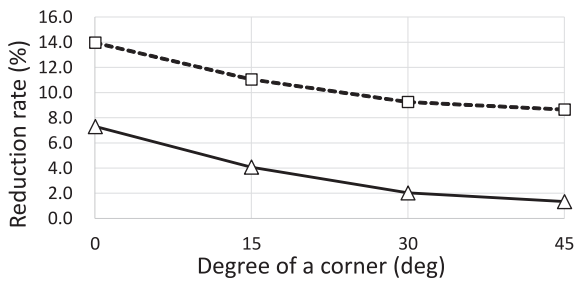

(e) reduction rate(Edge)

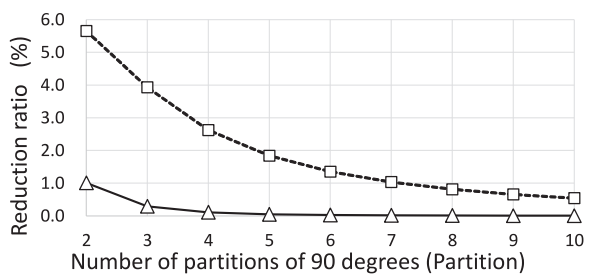

(f) reduction rate (Curve)

... Input data $\quad-\triangle$ Proposed method $\quad--\square-$-Conventional method

Fig. 26 Result of buried lines on an object

\subsection{2 補正処理のめり込み減少効果の評価実験}

次に，一般的なスプライン補正では，物体の角付近での目標 線が物体内にめり込んでしまう問題がある。これに対処した提 案補正方法のめり込み防止の効果を評価する。そこでまず，角 状 $\left(0,15,30,45^{\circ}\right)$ の目標線（例 Fig. 26 (a)，(b))，円周状 (90 を 2 10 分割で作成) の目標線（例 Fig. 26 (c)，(d)）の 2 種類を作成する。これらの結果例の図は，角や曲面上の目標 線（Input data）を横から見たものにならうようにプロットさ れている。この線について，スプライン補正 (Conventional) と提案方法（Proposed）により補正を行い，元の目標線の表す 角へのめり込み度合いを評価する。そのために，元の目標線の 長さと，生成された補正目標線の長さを比較した。Fig. $26(\mathrm{e})$, (f)のように元の目標線と提案方法を用いた補正目標線の長さ 


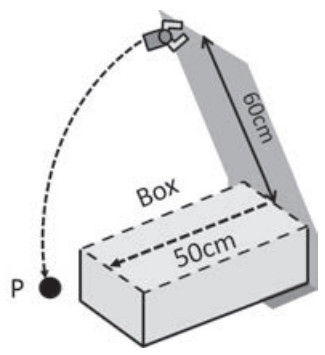

(a) experiment setting

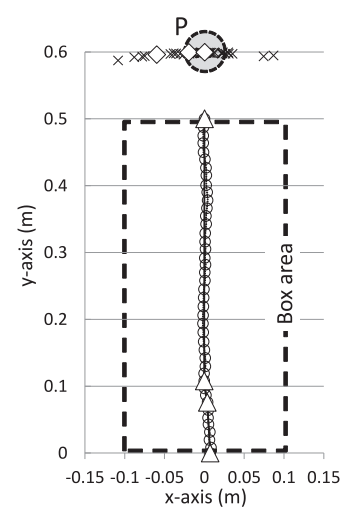

(b) result1

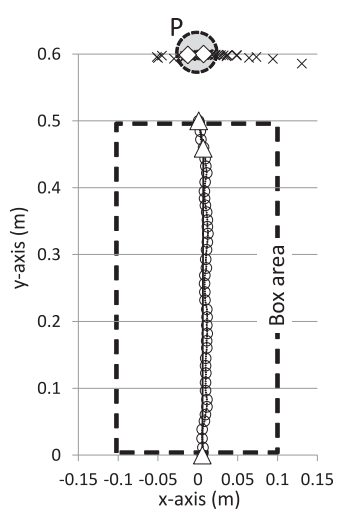

(c) result2 $\times$ Hand Path (input) $\diamond$ Hand path (smoothing) $\diamond$ Target line (input) $\triangleleft-$ Target line (smoothing)

Fig. 27 Result of hand pathes

の変化は角状, 円周状それぞれ一般的な補正方法より小さくな り，一般的な補正法よりめり込みを少なくしていることが分か る．布の巻き終わりが物体の角付近にあるケースでは，物体と 手先が接近する場合がある。このようなときに干渉回避システ ムが働いている場合, 動作が停止してしまう可能性がある. 本 手法を用いてめり込みを防ぐことにより，このような状況を減 らすことができる.

\section{2 .3 補正目標線を用いた手先経路の生成実験}

本実験では，補正目標線から生成される手先経路の評価を行 う. 本実験では，まず，実験 4.2.1 項で扱った直線上の入力目 標線と補正目標線を，Fig. 27 (a) のような箱上面を表す目標線 であると想定する。そして，箱を布で覆うために，60 [cm]の布 上目標線を作成し, この布上目標線と実験 4.2 .1 項の入力 10 回分の入力目標線と補正目標線より手先経路を生成した.

ここでまず，この箱上面の目標線から生成される手先経路が どのような位置にくるか説明する. Fig. 27 (a) の布を把持して いる手先が次に目指す手先位置について, 振れのない直線状の 目標線が箱上面に記されている場合, その目標線から生成され る経由点（手先経路を構成する点）は，すべて箱上平面の先に ある一点（点 $\mathbf{P}$ ) に生成される. しかし, 手振れの影響を受け た直線状の目標線の場合, その目標線から生成される経由点は 点 $\mathbf{P}$ の左右にふらついて生成されてしまう.

次に, 実際の入力 10 回分の目標線から生成された手先経路に ついて, Table 2 に評価結果を示す. 手先経路の経由点の数に
Table 2 Result of the hand path (Standard deviation)

\begin{tabular}{|l||c|c|}
\hline & $\mu_{s}[$ point $]$ & $\mu_{e}[\mathrm{~m}]$ \\
\hline \hline Input & $42.3(0.8)$ & $0.04(0.03)$ \\
\hline Smoothing & $5.2(2.4)$ & $0.03(0.01)$ \\
\hline Decreasing rate & $85 \%$ & \\
\hline
\end{tabular}

ついて, 10 回分の平均值を $\mu_{s}$ として示す. そして, 各経由点 の理想的な点 $\mathbf{P}$ からの誤差距離の平均を計算する. その平均距 離誤差の 10 回分の平均值を $\mu_{e}$ として示す. 加えて, 補正前と 補正後での経由点数の減少率を示す (カッコ内は標準偏差)。ま た, 経由点の左右の振れの典型例として, Fig. 27 (b), (c) に箱 上面から見た目標線と経由点を示す。これらのように，大幅に 入力時の手振れの影響によるふらつきを抑え, 経由点を減らす ことができているのが分かる，補正前の目標線からでは左右に 大きく繰り返して振れる手先経路を生成してしまい，この振れ は布を角にひっかけたり，大きな皺を生む原因となる，この問 題に対し，4.2.1 項の補正処理実験および，その線を用いた手 先経路生成の本実験により, 提案補正方法を用いることで, 大 きな左右への繰り返しの振れを，大幅に少なくすることができ ることを示した。

\section{3 大まかな指示を用いた教示による被覆操作}

この節では，提案した教示法によって作成された目標線を用 いて被覆が行えることを示す実験を行った. 実験には, 双腕口 ボット（Rethink 製 Baxter）を使用し，被覆に用いる布は綿製 のさらし布を用いた.

\subsection{1 凹凸を含む曲面形状への目標線を用いた被覆}

この実験では，凹凸を含む曲面物体を布で包む実験を行う． 初めに，幅の狭い布で Fig. 28 (a) に示す目標線ペアのように 物体を布で包むとする。このとき，布の幅より物体の埋める心゙ き凹部分は (Fig. $28(\mathrm{~b})$ ) の部分となる. デバイスから入力さ れたフイットライン群 (Fig. 28 (c)) が，凸化処理により埋め られ (Fig. $28($ d)), これから目標線, そして, その目標線ペア と把持点から手先経路を生成し（Fig. $28(\mathrm{e})$ )，被覆した結果を Fig. 28 (f) に示す.このように物体の考慮すべき凹部分のみを 埋めた目標線を生成し, 包むことができていることが分かる.

次に，幅の広い布でFig. 29 (a) に示す目標線ペアのように 物体を布で包むとする。このとき，布の幅より物体の埋めるべ き凹部分は, 幅の狭い布のときと違い（Fig. 29 (b)）の部分と なる，実際にデバイスで教示するとき，布の幅を考慮すること により，物体上部の半円柱からなる凹部分は埋めることができ， 布幅に適したフイットライン群（Fig. 29 (c)）を生成することが できた.さらにフィットライン群の凹部分が凸化処理により埋 められ (Fig. 29(d)), これから目標線, そして, その目標線ぺ アと把持点から手先経路を生成した（Fig. $29(\mathrm{e})$ ). 被覆した結 果として, Fig. 29 (f) に示すように, 物体の凹部分を考慮して 包むことができた．これらのように，布の幅に合わせて凹部分 を考慮し，被覆操作を行うことができた。

\section{3 .2 複数の目標線を用いた被覆}

この実験では, Fig. 30 (a) に示すような目標線を引き, 平包 みという包み方を行った. Fig. 30 (b) に示すように, 4 本の目標 線をデバイスで入力し, 手先経路を生成した. 以前の手先経路 


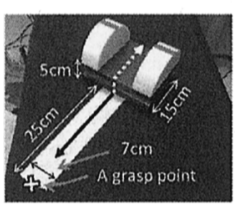

(a)

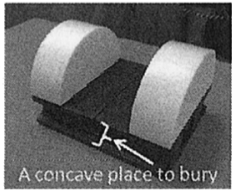

(b)

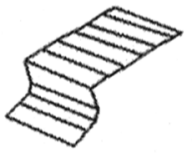

(c)

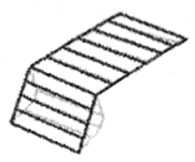

(d)

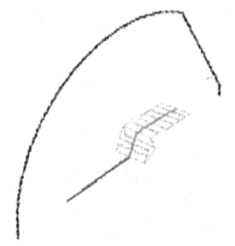

(e)

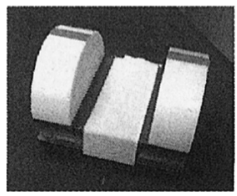

(f)
Fig. 28 Wrapping by a narrow cloth (a) plan of wrapping (b) concave places to bury (c) fit lines (d) convexed fit lines (e) target lines aand a hand path (f) result

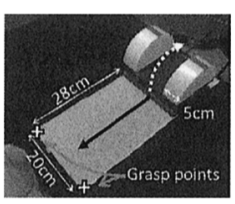

(a)

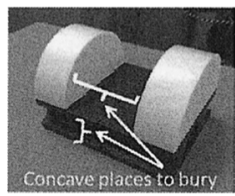

(b)

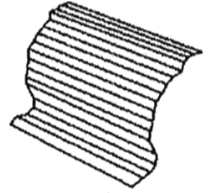

(c)

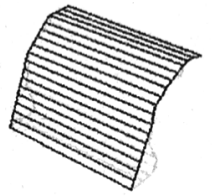

(d)

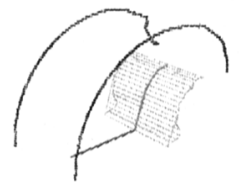

(e)

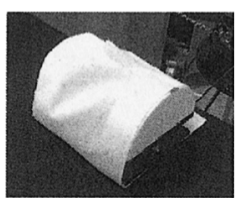

(f)
Fig. 29 Wrapping by a wide cloth (a) plan of wrapping (b) a concave place to bury (c) fit lines (d) convexed fit lines (e) target lines and a hand path (f) result

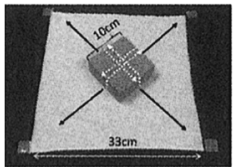

(a)

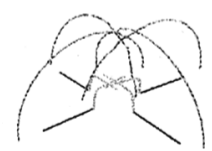

(b)

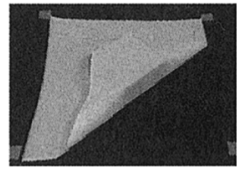

(c)

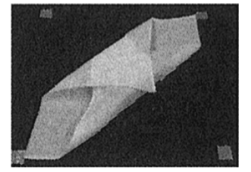

(d)

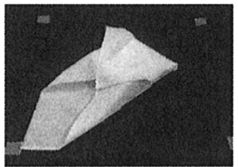

(e)

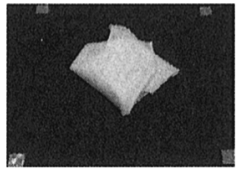

(f)
Fig. 30 Wrapping a box as Hira-Dutumi (a) plan of wrapping (b) target lines and hand pathes (c) 1st (d) 2nd (e) 3rd (f) result

生成方法では, 例えば長方形の布の中心を通るような, 布の辺 に平行な布上目標線しか用いることができなかった。これに対 し本システムでは，改良した手先経路生成方法を用いているた め, 布の対角線上に布上目標線が引かれているような場合でも, 手先経路を生成することができる。これを用いて，ロボットは Fig. 30 (c) 〜 (e) に示すように箱を包んでいく.そして, 結果と して Fig. 30 (f) に示すように，箱を平包みすることができた.

\section{4 考察}

本手法を用いた被覆実験 4.3 節の結果のように, 今回の目標 である，覆うべきでない領域は避け，覆うべき領域に布を覆う という，被覆の本質的な作業を果たすことができた，ただし，実 用的な被覆操作という観点から, 綺麗に犓なく包装するといっ た作業を次に考える場合，実験結果には，布の伸び，弛みの影 響による布の沈みや㱀という課題が現れてくる.この布の㱀や 弛みを手先経路の調整で取り除けば，実用的な包装作業にまで 達することができると考える.

これら布の㱀や弛みといった問題は, 布の正確な力学モデル をもつことにより予測や追跡がある程度は可能であろうが, 最 終的には動作時に視覚・覚を用いて布の状態を監視しながら適 宜解消していくことが必要になると考えられる。こういった問 題に関する先行研究としては, 力覚を用いたテンション調整によ る柔軟物操作時のローカルな位置調整を行っている研究 [22] [23] が挙げられる。これらの研究は視覚による布のセンシングとと もに，力覚に基づく調整を合わせて操作を行っている．ここで 人間が被覆を行う場合を考えてみると，多くの場合，使用する 布と対象物体を見て事前に経路を計画して被覆動作を行ってい るが，そのうえで，事前に予測しづらい㱀やたるみに対しては 視覚や力覚のからのフィードバックによりその都度, 経路を微 調整している，これらを考えると，㱀や弛みへの対応は，ローカ ルな動作修正として全体の作業計画とは独立に実装されるのが 自然である. したがって, 今後の研究で㱀や弛みの問題に対処 するために本手法を拡張する場合にも, 本論文で示した動作生 成の流れを根本的に変更するのではなく, ローカルな動作補正 を本手法に追加する形で拡張してゆくことになろう。逆に，視 覚・覚を用いた補正動作生成の観点から見ても, 全体的な作 業計画がある上でのローカルな調整としてアルゴリズムを構築 する方が，より的確な視覚・覚フィードバックを実現できる と期待できる.

\section{5.おわりに}

本論文では，ロボットによる布被覆操作を目指し，大まかな 指示に含まれている意図を理解し，適切な中間表現を生成する 手法を提案した。この提案手法を用いることにより，人間の大 まかな指示から，三階層モデルによる中間表現を通して，凹凸 を持つ曲面形状の物体への被覆作業の記述および，実行をする ことができた。これにより，ユーザは複雑な被覆操作の指示を， 大まかな指示により，ロボットへ直観的に伝えることができる ようになった，提案手法の中では，大まかな指示を解釈するた めの手振れと物体の凹凸考慮の問題を挙げ, 目標線への手振れ の影響を補正する方法と，被覆に適した凸包領域の生成方法に ついて述べた。 また，以前報告した手先経路生成方法について は, 以前は長方形状の布であり, かつ, 布の辺と平行な布上目 標線にしか使用できない問題があった。そのため，本論文では それ以外の布や布上目標線でも手先経路を生成できる改良方法 を提案した。

実験では，提案手法が，手振れを考慮しながら人間の大まか な指示を解釈し，被覆操作を目標線として記述，実行できるこ とを示した。その中で，凹凸のある物体を包む実験では，布の 
形状から埋めるべき凹凸を考慮し物体を包み，提案した凹凸処 理方法の効果を示した. 次に，箱への平包み実験では，布の対 角線上に引いた複数の目標線を用いて物体を包み，提案した手 先経路生成方法の効果を示した.

今後は，凹凸や曲面を含む物体への何周もの巻き付けといっ たより複雑な作業を行っていく，このとき，ロボットアームの可 動範囲や手先の回転角の制約，物体とロボットアームの干渉問 題が発生すると考えられる。この問題を避け，手先軌道通りに 布を動かすためには，動作中に布の持ち替えが必要となる。こ のような作業を行うための教示作業では, 今回, 提案した局所 凸化処理の効果がより発揮されていく.

\section{参 考 文 献}

[1] A. Ramisa, G. Aleny Ãă, F. Moreno-noguer and C. Torras: "Using depth and appearance features for informed robot grasping of highly wrinkled clothes," International Conference on Robotics and Automation, pp.1703-1708, 2012.

[2] Y. Kita, F. Saito and N. Kita: "A deformable model driven visual method for handling clothes," International Conference on Robotics and Automation, pp.3889-3895, 2004.

[3] C. Bersch, B. Pitzer and S. Kammel: "Bimanual robotic cloth manipulation for laundry folding," International Conference on Intelligent Robots and Systems, pp.1413-1419, 2011.

[4] C. Elbrechter, R. Haschke and H. Ritter: "Bi-Manual Robotic Paper Manipulation Based on Real-Time Marker Tracking and Physical Modelling," International Conference on Intelligent Robots and Systems, pp.1427-1432, 2011.

[ 5 ] K. Nagata and N. Yamanobe: "Picking up a Towel by Cooperation of Functional Finger Actions," International Conference on Intelligent Robots and Systems, pp.1785-1790, 2009.

[6] 小野栄一, 喜多伸之, 坂根茂幸: “視触覚を用いた輪郭情報に基づ く折れ重なった布生地の展開”, 日本ロボット学会誌, vol.15, no.2, pp.275-283, 1997.

[ 7 ] 和田隆広, 平井慎一, 川村貞夫： “面状柔軟物体上の複数点の間接的同 時位置決め作業の解析とプランニング”, 日本ロボット学会誌, vol.18, no.5, pp.675-682, 2000

[ 8 ] 柴田瑞穂, 太田剛士, 平井慎一：“摘み滑り動作を利用した布地の展 開動作”，日本ロボット学会誌，vol.27, no.9, pp.1029-1036, 2009.

[ 9 ] S. Miller, J. van den Berg, M. Fritz, T. Darrell, K. Goldberg and P. Abbeel: "A Geometric Approach to Robotic Laundry Folding," International Journal of Robotics Research, vol.31, no.2, pp.249-267, 2012.

[10] H. Terada and K. Yagata: "Motion Planning Approach of a Multi-Robot System for "Furoshiki" Wrapping Operation," Journal of the Japan Society of Precision Engineering, vol.76, no.5, pp.546-551, 2010

[11] R. Oya, K. Nagahama, K. Miyake, K. Yamazaki, K. Okada and M. Inaba: "Dressing assistance with failure recovery actions based on cloth states' recognition," The Robotics and Mechatronics Conference, 2A2-Q13, 2013.

[12] T. Tamei, T. Matsubara, A. Rai and T. Shibata: "Reinforcement Learning of Clothing Assistance with a Dual-arm Robot," International Conference on Humanoid Robots, pp.733-738, 2011.

[13] T. Igarashi and J.F. Hughes: "Clothing Manipulation," ACM Symposium on User Interface Software and Technology, pp.91100,2002

[14] H. Wang and T. Komura: "Manipulation of Flexible Objects by Geodesic Control," Computer Graphics Forum, vol.31, no.2, pp.499-508, 2012.

[15] N. Hayashi, T. Tomizawa, T. Suehiro and S. Kudoh: "Dual Arm Robot Fabric Wrapping Operation Using Target Lines," International Conference on Robotics and Biomimetics, pp.2185-2190, 2014.

[16] D. McCallum and D. Avis: "A linear algorithm for finding the convex hull of a simple polygon," Information Processing Letters, vol.9, issue.5, pp.201-206, 1979.

[17] F.P. Preparata and S.J. Hong: "Convex Hulls of Finite Sets of Points in Two and Three Dimensions," Communications of the ACM, vol.20, no.2, pp.87-93, 1977.

[18] E. Rahtu, M. Salo and J. Heikkilä: "A new convexity measure based on a probabilistic interpretation of images," IEEE Transactions on Pattern Analysis and Machine Intelligence, vol.28, no.9, pp.1501-1512, 2006.

[19] C. Bajaj and T.K. Dey: "Convex decomposition of polyhedra and robustness," SIAM Journal on Computing, vol.21, no.2, pp.339-364, 1992.

[20] J.-M. Lien and N.M. Amato: "Approximate convex decomposition of polyhedra," Proc. of the 2007 ACM Symposium on Solid and Physical Modeling, pp.121-131, 2007.

[21] Robot Operating System, http://www.ros.org（2016 年 3 月 現在）

[22] A. Lee, H. Lu, A. Gupta, S. Levine and P. Abbeel: "Learning Force-Based Manipulation of Deformable Objects from Multiple Demonstrations," International Conference on Robotics and Automation, pp.177-184, 2015.

[23] A. Colomé, A. Planells and C. Torras: "A Friction-ModelBased Framework for Reinforcement Learning of Robotic Tasks in Non-Rigid Environments," International Conference on Robotics and Automation, pp.5649-5654, 2015.

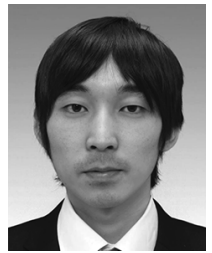

林 直宏 (Naohiro Hayashi)

2013 年電気通信大学大学院情報システム学研究科 博士前期課程修了, 修士 (工学). 現在, 電気通信 大学大学院情報システム学研究科博士後期課程在学 中.ヒューマノイドの動作生成やマニピュレータに よる柔軟物操作といった，人間の巧みな動作のモデ ル化の研究に従事.（日本ロボット学会学生会員）

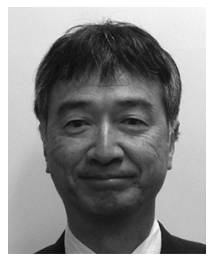

末廣尚士（Takashi Suehiro）

1980 年東京大学大学院修士課程修了, 同年産業技術 総合研究所（旧電子技術総合研究所）に入所. 1990 年東京大学博士 (工学). 2009 年より電気通信大学 大学院情報システム学研究科教授. 現在同大学大学 院情報理工学研究科教授. マニピュレータを中心と したロボットシステムの研究に従事。

(日本ロボット学会正会員)

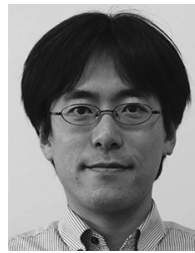

冨沢哲雄（Tetsuo Tomizawa）

2006 年筑波大学大学院システム情報工学研究科博 士課程修了, 博士 (工学). JSPS 特別研究員, 産業 技術総合研究所特別研究員を経て, 2016 年より防衛 大学校情報工学科講師. 人間共存環境で働くロボッ 卜に関する研究に従事。（日本ロボット学会正会員

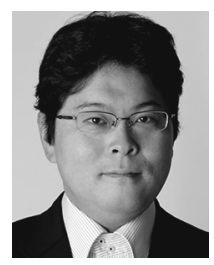

工藤俊亮 (Shunsuke Kudoh)

2005 年東京大学大学院情報理工学系研究科博士課 程修了, 博士 (情報理工学). 同年同大学生産技術研 究所特任助教. 2010 年電気通信大学 大学院情報シ ステム学研究科准教授. 現在同大学大学院情報理工 学研究科准教授. 人間動作の解析やロボットの見ま ね学習の研究に従事。（日本ロボット学会正会員） 